\title{
Test of a Modified Rainfall-Runoff Model in East-Central Greece
}

\section{Giakoumakis $\mathrm{S}^{*}$ and Tigkas D \\ School of Rural and Surveying Eng., National Technical University of Athens, Greece}

*Corresponding author: Spyros Giakoumakis, School of Rural and Surveying Eng, National Technical University of Athens, Greece, Email: sgiakou@central.ntua.gr

\section{Research article}

Volume 4 Issue 2

Received Date: March 11, 2020

Published Date: April 01, 2020

DOI: $10.23880 /$ jenr-16000193

\section{Abstract}

In this article a modified version of the Simple Water Balance (SWB) model, comprising here three parameters instead of one, was used. The modified model was tested in large-scale river basins in east-central Greece, upstream two hydrometric stations. The available historic runoff records comprised 19 hydrologic years each, on a monthly basis. Thirteen among them were used for calibrating the model, whereas the six subsequent, for validating it. Two different efficiency criteria were used as a measure of performance of the modified model. Their values, calculated for both calibration and validation stages, were close and relatively high. Thus, keeping in mind both the size and complexity of the river basins studied, one can conclude that the modified model, despite its lumped form, fits satisfactorily the historic runoff series.

Keywords: Rainfall-Runoff Model; Large-Scale River Basins; Calibration; Validation

\section{Introduction}

As rainfall-runoff model is defined a set of mathematical relationships that correlate rainfall with runoff [1]. Depending upon the kind of equations used rainfall-runoff models are divided into three general categories: 1 . black box, 2. conceptual and 3. Physically-based.

Among them, conceptual rainfall-runoff models are a common tool for the assessment of runoff in river basins. Nevertheless, most of them include many parameters, which have to be estimated [2-6]. In order to overcome this disadvantage, in the present work the well-known monoparametric Simple Water Balance (SWB) model Diskin, et al. [7] was improved adding two more parameters in such a way that it can also take into account both deep percolation losses and groundwater storage.

The modified model was tested in Pinios river basin in east-central Greece, upstream Ali Efendi and Larissa hydrometric stations.
Our purpose was to show that, despite its simplistic concept and lumped form, the modified SWB model performs satisfactorily, even in hydrologically complex river systems, such as these of the river basins chosen for this study.

\section{Theory}

The SWB model is based on the assumption that the water storage in the river basin takes place in the upper soil zone (i.e. root zone) [8]. In this work, a modified threeparametric version of this model has been used. A schematic representation of the modified model is given in Figure 1. According to this figure, Si (mm) represents the available water for any month i (soil moisture) and Smax is a parameter representing the total soil storage capacity. The monthly soil moisture deficit is then represented by the difference Smax - Si, averaged over the river basin. The water depth Si in the soil increases by the monthly precipitation $\mathrm{Pi}$ and is depleted by both the monthly potential evapotranspiration Ei and the deep percolation losses Di. 


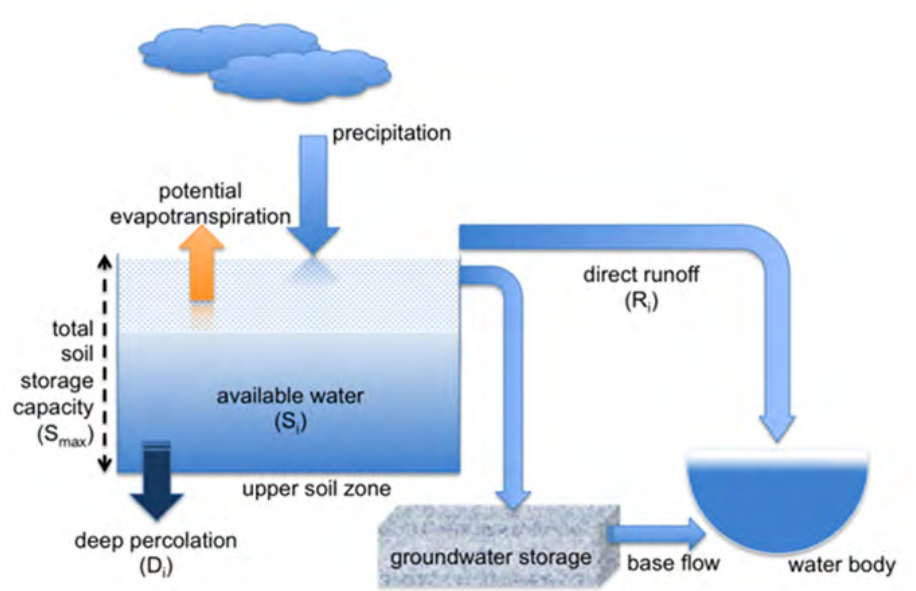

Figure 1: Schematic representation of the modified SWB model.

As a first step, a trial depth of the soil moisture $\mathrm{Si}^{\prime}$ is computed by:

$$
\mathrm{Si}^{\prime}=\mathrm{Si}-1+\mathrm{Pi}-\mathrm{Ei}(\mathrm{mm})(1)
$$

Where:

Si-1: soil moisture for the month i-1 (mm)

$\mathrm{Pi}$ : precipitation for the month i ( $\mathrm{mm})$

Ei : potential evapotranspiration for the month i (mm)

Monthly direct runoff Ri (excess water) depends on the value of Si' (Eq.1). Thus: If Si' > Smax

$$
\begin{gathered}
\mathrm{Ri}=\left(\mathrm{Si}^{\prime}-\mathrm{Smax}\right)-\mathrm{K}^{\prime}{ }^{(2)} \\
\mathrm{Di}=\left(\mathrm{Si}^{\prime}-\mathrm{Smax}\right)-\mathrm{K} \\
\mathrm{Si}=\mathrm{Smax}(4)
\end{gathered}
$$

Where:

$$
\mathrm{K}>=1-\mathrm{K}
$$

Di : deep percolation losses for the month i (mm)

$\mathrm{K}$ : separation parameter $(0 \leq \mathrm{K} \leq 1)$ If $0 \leq \mathrm{Si}^{\prime} \leq \mathrm{Smax}$

$$
\begin{aligned}
& \mathrm{Ri}=0 \text { (5) } \\
& \mathrm{Si}=\mathrm{Si}^{\prime}(6) \\
& \mathrm{Di}=0
\end{aligned}
$$

$$
\begin{aligned}
& \text { If } \mathrm{Si}^{\prime}<0 \\
& \mathrm{Ri}=0 \text { (8) } \\
& \mathrm{Si}=0(9) \\
& \mathrm{Di}=0(10)
\end{aligned}
$$

Calculated runoff $\mathrm{Ri}$ is mainly concentrated in the winter months, because the model does not take into account the groundwater storage. In order to overcome this disadvantage, the following equation is proposed: -

$$
\mathrm{Qi}=\mathrm{a}-\mathrm{Ri}+(1-\mathrm{a})-\mathrm{Q} \mathrm{i}-1
$$

Where Qi is a more accurate approximation of the runoff $\mathrm{Ri}$ with ' $\alpha$ ' being a lag parameter $(0<a \leq 1)$. This parameter expresses the delay of rainfall's conversion to runoff. Values close to 0 correspond to a long delay and as a result, runoff is transposed to spring and summer months, whereas values close to 1 , correspond to an instant response of the river basin and thus, instant runoff formation.

The efficiency of each simulation performed, was checked by the well-known NSE coefficient, given from the following equation [9].

$$
\mathrm{NSE}=\frac{\left\{\sum(\text { yoi }- \text { yo }) 2-\sum(\text { yoi }- \text { yci }) 2\right\}}{\sum(\text { yoi }- \text { yo }) 2}
$$


Where:

yoi: observed monthly runoff for the month i (mm) ỹo: mean value of observed monthly runoff $(\mathrm{mm})$ yci: computed monthly runoff for the month i (mm)

As an additional criterion for model performance was used the ratio of the sum of the computed monthly runoff over the sum of the observed monthly runoff [10].

$$
\mathrm{r}=\frac{\sum \mathrm{yci}}{\sum \mathrm{yoi}}
$$

The nearer to unity the values of NSE and $r$ calculated from Eq. (12) and Eq. (13) respectively are, the better the suitability of the model for describing the rainfall-runoff process.

\section{Results and Discussion}

The modified model was implemented in Pinios river basin in Thessalia (east-central Greece) upstream two different hydrometric stations, i.e. Ali Efendi of an upstream basin area of $2714.4 \mathrm{~km}^{2}$ and Larissa, of an upstream area of $6529.7 \mathrm{~km}^{2}$ (Figure 2). Pinios river basin is a huge flat plain surrounded by high mountains, the largest in Greece. The mean annual areal precipitation upstream Larissa hydrometric station is equal to $871.2 \mathrm{~mm}$ [11]. Geology of the Pinios river basin is mostly composed by flysch, limestone and alluvial deposits in lower altitude areas [12].

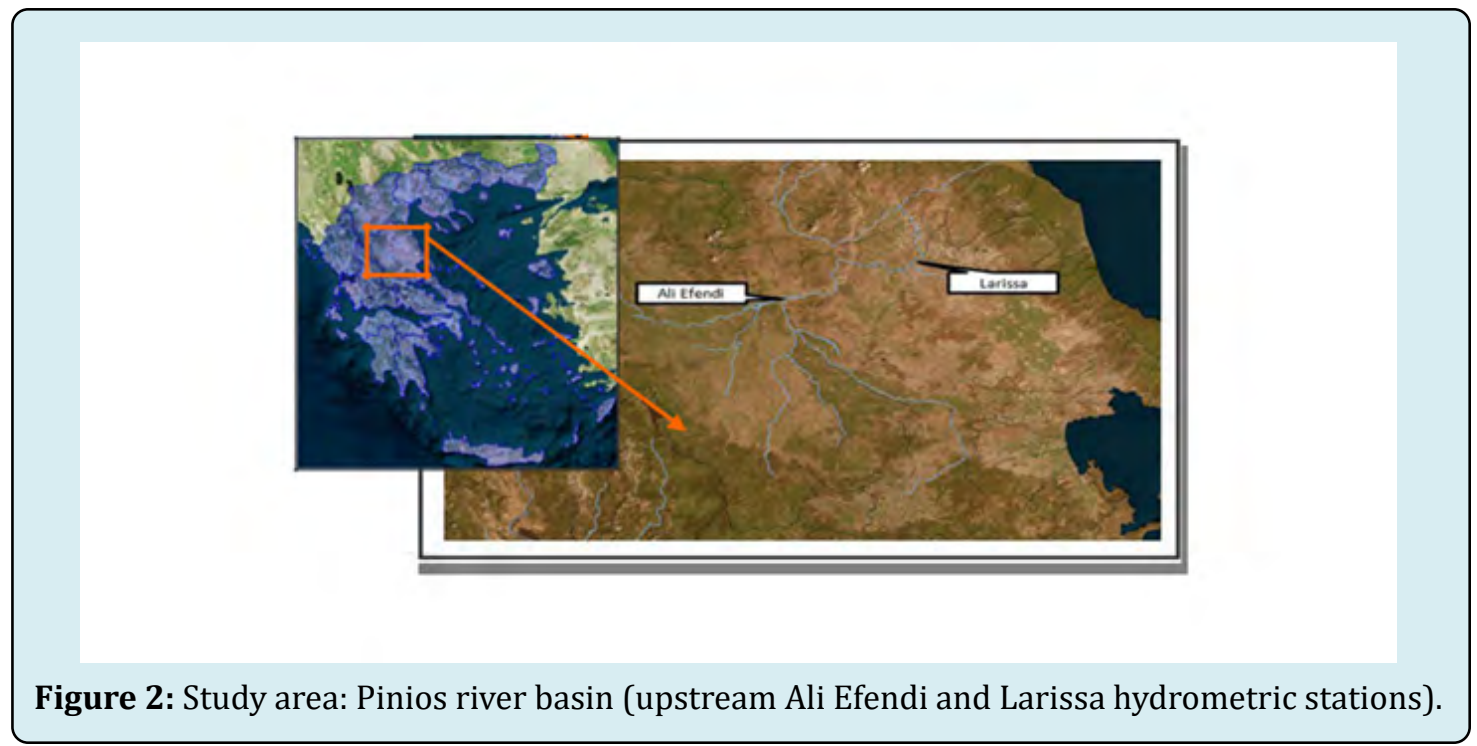

In Table 1 the main characteristics of each river basin at the sites of interest are presented [11].

\begin{tabular}{|c|c|c|}
\hline River basins' characteristics & Ali Efendi & Larissa \\
\hline Area (km2) & 2714.4 & 6529.7 \\
\hline Mean elevation (m) & 539.7 & 414.9 \\
\hline
\end{tabular}

Table 1: Main characteristics of the river basins studied.

Input data (monthly areal precipitation and potential evapotranspiration values) for feeding the model, concern a period of 19 hydrologic years for which, measured monthly runoff data were also available for each case considered [12]. For the calibration of the model, data of the first 13 hydrologic years were used, whereas for the validation, data of the subsequent 6 hydrologic years of the 19 total available were taken. Calibration procedure was carried out by applying a trial and error technique $[13,14]$. In Table 2 are presented the basic statistics on annual basis of the two historic runoff time series for Ali Efendi and Larissa hydrometric stations, respectively (i.e. Mean Annual Runoff M.A.R. and standard deviation STD).

\begin{tabular}{|c|c|c|}
\hline & Ali Efendi & Larissa \\
\hline M.A.R. $(\mathrm{mm})$ & 355.9 & 420.9 \\
\hline STD $(\mathrm{mm})$ & 162.2 & 195.7 \\
\hline
\end{tabular}

Table 2: Basic statistics of the historic runoff time series on annual basis.

\begin{tabular}{|c|c|c|}
\hline Parameter & Ali Efendi & Larissa \\
\hline $\mathrm{S}_{\max }(\mathrm{mm})$ & 130 & 152 \\
\hline $\mathrm{K}$ & 0.05 & 0.12 \\
\hline $\mathrm{a}$ & 0.45 & 0.48 \\
\hline
\end{tabular}

Table 3: Optimum set of values of model's parameters. 


\section{Journal of Ecology and Natural Resources}

In Table 3 the optimum set of values of the parameters of the model, determined during calibration, is presented for each case considered.
Both NSE and r values, for both calibration and validation periods, for the two cases considered, are summarized in Table 4.

\begin{tabular}{|c|c|c|c|c|}
\hline River basin & Calibration & \multicolumn{2}{|c|}{ Validation } \\
\hline & NSE & $\mathrm{r}$ & NSE & $\mathrm{r}$ \\
\hline Pinios (Ali Efendi) & 0.81 & 1.0 & 0.68 & 0.94 \\
\hline Pinios (Larissa) & 0.83 & 1.0 & $0.65^{*}$ & $0.89^{*}$ \\
\hline \multicolumn{2}{|r}{} & 0.53 & 0.99 \\
\hline
\end{tabular}

$\left({ }^{*}\right)$ without considering the extreme runoff value of March 1987 (Figure 3b)

Table 4: Values of NSE and $r$ for calibration and validation periods.

In Figure 3 results are presented on a monthly basis for: (a) Ali Efendi and (b) Larissa hydrometric stations. It can be observed that simulated runoff follows the variations of the measured one for both calibration and validation periods, at the two sites considered, with the exception of the extremely high runoff value for March of the hydrologic year 1986-87 (last validation year/case of Larissa).
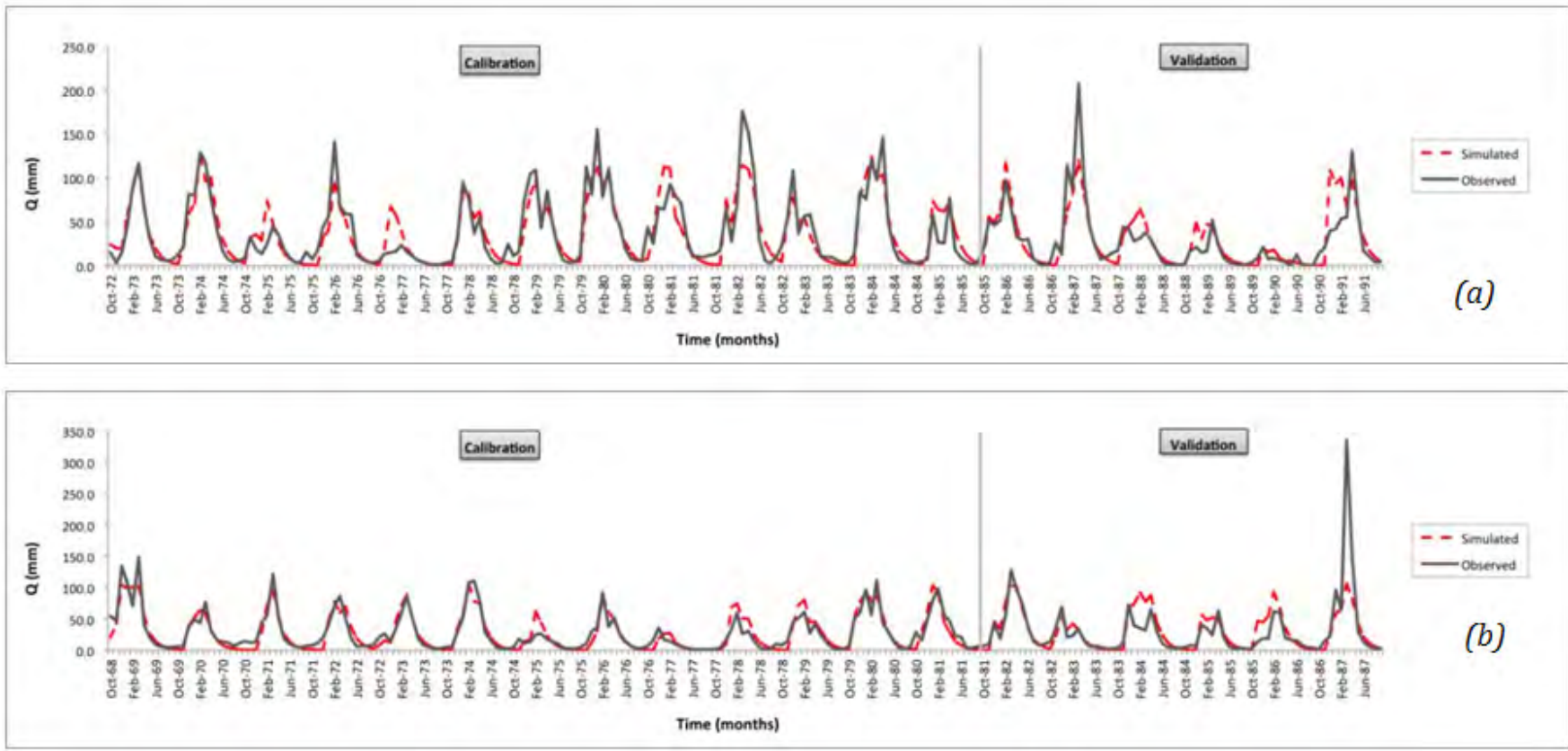

Figure 3: Monthly runoff variation for model's calibration and validation periods at: (a) Ali Efendi and (b) Larissa hydrometric stations.

\section{Concluding Remarks}

A three-parametric rainfall-runoff model was used in large-scale river basins in east-central Greece. Model calibration was performed using a 13-year runoff record on a monthly basis from Ali Efendi and Larissa hydrometric stations of the Pinios river basin. The suitability of the model was checked by the efficiency criteria NSE (Eq. 12) and r (Eq.
13). Model validation was carried out using monthly runoff data of the subsequent 6 hydrologic years of the available corresponding runoff series. It was shown that both NSE and $\mathrm{r}$ values remained close to those of calibration and relatively high.

Satisfactory model's performance proved that the model, thanks to its simplicity, can be seen as a useful tool for no 
time consuming hydrologic simulation, even in complex and large-scale river basins such as these chosen in this study.

\section{References}

1. Nalbantis I (2007) Protection and Water Resources Management. NTUA, pp: 180.

2. Phanartzis CA (1972) "Morphou-Tylliria Feasibility Studies". Simulation of watershed runoff in MorphouTylliria area. AGL: SF/CYP.513, Technical Report.

3. Viessman W, Lewis GL, Knapp JW (1989) Introduction to Hydrology, third edition, Harper \& Row, Publishers, New York.

4. Crooks SM, Kay AL, Davies HN, Bell VA (2014) From Catchment to National Scale Rainfall-Runoff Modelling: Demonstration of a Hydrological Modelling Frameowrk. Hydrology 1(1): 63-68.

5. Fowler KJA, Peel MC, Western AW, Lu Zhang L, Peterson TJ (2016) Simulating runoff under changing climatic conditions: Revisiting an apparent deficiency of conceptual rainfall-runoff models. Water Resources Research 52(3): 1820-1846.

6. Sitterson J, Knightes C, Parmar R, Wolfe K, Muche M, et al. (2017) An Overview of Rainfall-Runoff Model Types, EPA/600/R-14/152.

7. Diskin MH, Buras N, Zamir S (1973) Application of a Simple Hydrologic Model for Rainfall-Runoff relations of the Dalton watershed. Water Resources Research 9(4): 927-936.

8. Giakoumakis S, Tsakiris G, Efremides D (1991) On the rainfall-runoff modelling in a Mediterranean island environment. Advances in Water Resources Technology. In: Tsakiris G, et al. (Eds.), Balkema, Rotterdam, pp: 137148.

9. Nash JE, Sutcliffe JV (1970) River flow forecasting through conceptual models, Part I - A discussion of principles. Journal of Hydrology 10(3): 282-290.

10. Mimikou M, Kouvopoulos Y, Cavadias G, Vayianos N (1991) Regional Hydrological Effects of Climate Change. Journal of Hydrology 123(1-2): 119-146.

11. Xanthopoulou E, Mamassis N, Anastasopoulou P, Alexopoulou K (1997) Research Project: Upgrading and Updating of Hydrological Information of ThessaliaUpdating of hydrometeorological data, Vol. 1, National Technical University of Athens, Athens, Greece, pp: 240 (in Greek), Scientific Director: D. Koutsoyiannis, Principal Investigator: I. Nalbantis.

12. Nalbantis I, Koutsoyiannis D (1997) Research Project: Upgrading and Updating of Hydrological Information of Thessalia-Final Report, Vol. 4, National Technical University of Athens, Athens, Greece, pp: 78 (in Greek), Scientific Director: D. Koutsoyiannis, Principal Investigator: I. Nalbantis.

13. Tigkas D, Tsakiris G (2004) Medbasin: A Mediterranean rainfall-runoff software package, European Water, 5/6: 3-11.

14. Tigkas D, Vangelis H, Tsakiris G (2012) Drought and climatic change impact on streamflow in small watersheds. Science of the Total Environment 440: 3341.

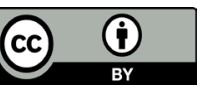

